Research Article

www.ijrap.net

\title{
HEPATOPROTECTIVE AND ANTIOXIDANT ACTIVITY OF CANSCORA PERFOLIATA LAM (GENTIANACEAE) AGAINST CCL 4 INDUCED HEPATOTOXICITY IN RATS
}

Thangakrishnakumari $\mathrm{S}^{1}$, Nishanthini $\mathrm{A}^{2}$, Muthukumarasamy $\mathrm{S}^{1}$, Mohan V.R ${ }^{2 *}$

${ }^{1}$ Department of Botany, Sri K.G.S. Arts College, Srivaikuntam, Tamil Nadu, India

${ }^{2}$ Ethnopharmacology Unit, Research Department of Botany, V. O. Chidambaram College, Tuticorin, Tamil Nadu, India

Received on: 13/08/12 Revised on: 09/10/12 Accepted on: 04/11/12

\author{
*Corresponding author \\ E-mail: vrmohanvoc@gmail.com \\ DOI: 10.7897/2277-4343.03628 \\ Published by Moksha Publishing House. Website www.mokshaph.com \\ All rights reserved.
}

\section{ABSTRACT}

The aim of the study was to investigate the hepatoprotective activity of ethanol extract of whole plant of Canscora perfoliata in $\mathrm{CCl}_{4}$ induced hepatotoxic rats. Administration of hepatotoxins $\left(\mathrm{CCl}_{4}\right)$ showed significant elevation of serum SGOT, SGPT, ALP, bilirubin, conjugated, unconjugated bilirubin and lipid peroxidation. Treatment with Canscora perfoliata (150 and $300 \mathrm{mg} / \mathrm{kg})$ significantly reduced the above mentioned parameters. The plant extract also enhanced the antioxidant activity. The ethanol extract of Canscora perfoliata have significant effect on the $\mathrm{CCl}_{4}$ induced hepatotoxicity animal models.

Keywords: Hepatoprotective activity, Antioxidant, $\mathrm{CCl}_{4}$, Bilirubin, MDA

\section{INTRODUCTION}

Liver is one of the largest organs in the human body and carries out various functions like carbohydrate, protein and fat metabolism, detoxification, secretion of bile and storage of vitamins ${ }^{1}$. Liver disease is still a worldwide health problem. Jaundice and hepatitis are two major hepatic disorders that account for high death rate $^{2}$. Unfortunately, conventional or synthetic drugs used in the treatment of liver diseases are inadequate and sometimes can have serious side effects ${ }^{3}$.

The attention of pharmacologists throughout the world has been focused on findings out safer and potent hepatoprotective drug. The natural products today symbolize safety in contrast to the synthetic drugs that are regarded as unsafe to humans and environment. So, people are returning to the natural product with the hope of safety and security ${ }^{4}$. However, so far there is no systematic study on hepatoprotective activity has been reported on the selected plant in the literature. Hence the present study focuses on evaluating the hepatoprotective activity of whole plant of Canscora perfoliata.

Canscora perfoliata Lam is one of the medicinally important plant belonging to Gentianaceae. The juice prepared from the plant is given to treat any poisonous bites by Palliyar tribals of Grizzled Giant Squirrel Wildlife Sanctuary, Srivilliputhur, Western Ghats, Tamil $\mathrm{Nadu}^{5}$. However, perusal of literature reveals that, hepatoprotective activity of Canscora perfoliata is totally lacking and hence the present investigation was undertaken.

Carbon tetrachloride $\left(\mathrm{CCl}_{4}\right)$ is one of the most commonly used hepatotoxins in the experimental study of liver diseases. The hepatotoxic effect of $\mathrm{CCl}_{4}$ is largely due to its active metabolite, trichloromethyl radical $^{6}$. The administration of $\mathrm{CCl}_{4}$ in rats enhances hepatic protein oxidation and results in the accumulation of $\mathrm{CCl}_{4}$ oxidized proteins in the liver ${ }^{7}$. The present study was conducted to elevate the hepatoprotective effect of the extracts of whole plant of Canscora perfoliata on carbon tetrachloride induced liver damage in experimental rats.

\section{MATERIALS AND METHODS \\ Plant material}

The whole plant of Canscora perfoliata Lam were collected from the natural forests of Western Ghats at Thanniparai, Srivilliputhur, Virudhunagar District, Tamil Nadu and identified by the Botanical Survey of India, Coimbatore. A voucher specimen (VOCB 1637) was retained in Ethnopharmacology Unit, Research Department of Botany, V. O. Chidambaram College, Tuticorin for further reference.

Preparation of plant extracts for Phytochemical Screening and Hepatoprotective Studies

The whole plant was dried under shade and then powdered with a mechanical grinder to obtain a coarse powder, which was then subjected to successive extraction in a Soxhlet apparatus using ethanol. The extract was subjected to qualitative test for the identification of various phytochemical constituents as per standard procedures ${ }^{8,9,10}$. The ethanol extracts were concentrated in a rotary evaporator. The concentrated ethanol extract were used for hepatoprotective studies.

\section{Animals}

Normal healthy male Wistar albino rats (180-240g) were used for the present investigation. Animals were housed under standard environmental conditions at room temperature $\left(25 \pm 2^{\circ} \mathrm{C}\right)$ and light and dark (12:12h). Rats were fed with standard pellet diet (Goldmohur brand, MS Hindustan lever Ltd., Mumbai, India) and water ad libitum. Study was carried out as per IAFC approval No: 82/PHARMA/SCRI,2010.

\section{Acute Toxicity Studies}

Acute oral toxicity study was performed as per OECD423 guidelines (acute toxic class method), albino rats 
$(n=6)$ of either sex selected by random sampling were used for acute toxicity study ${ }^{11}$. The animals were kept fasting for overnight and provided only water, after which the extracts were administered orally at $5 \mathrm{mg} / \mathrm{kg}$ body weight by gastric intubations and observed for 14 days. If mortality was observed in two out of three animals, then the dose administered was assigned as toxic dose. If mortality was observed in one animal, then the same dose was repeated again to confirm the toxic dose. If mortality was not observed, the procedure was repeated for higher doses such as 50, 100 and $2000 \mathrm{mg} / \mathrm{kg}$ body weight.

\section{Experimental Design}

In the investigation, a total of 25 rats $\left(\mathrm{CCl}_{4}\right.$ hepatic toxicity induced rats and 5 normal rats) were taken and divided into five groups of 5 rats each.

Group I: Rats received normal saline was served as a normal control.

Group II: $\mathrm{CCl}_{4}$ hepatic toxicity induced control: Rats received $2.5 \mathrm{ml} / \mathrm{kg}$ body weight of $\mathrm{CCl}_{4}$ for 14 days.

Group III: Liver injured rats received ethanol extract of whole plant of Canscora perfoliata at the dose of $150 \mathrm{mg} / \mathrm{kg}$ body weight for 14 days.

Group IV: Liver injured rats received ethanol extract of whole plant of Canscora perfoliata at the dose of $300 \mathrm{mg} / \mathrm{kg}$ body weight for 14 days.

Group V: Liver injured rats received standard drug silymarin at the dose of $100 \mathrm{mg} / \mathrm{kg}$ body weight for 14 days.

\section{Biochemical Analysis}

The animals were sacrificed at the end of experimental period of 14 days by decapitation. Blood was collected, sera separated by centrifugation at 3000rpm for 10 minutes. Serum protein $^{12}$ and serum albumins was determined quantitatively by colorimetric method using bromocresol green. The total protein minus the albumin gives the globulin. Serum glutamate pyruvate transaminase (SGPT) and serum glutamate oxaloacetate transaminase (SGOT) was measured spectrophotometrically by using the method of Reitman and Frankel ${ }^{13}$. Serum alkaline phosphatase (ALP) was measured by the method of King and Armstrong ${ }^{14}$.

Total bilirubin and conjugated bilirubin were determined as described by Balistrei and Shaw ${ }^{15}$. The unconjugated bilirubin concentrations were calculated as the difference between total and conjugated bilirubin concentrations. Liver homogenates $(10 \% \mathrm{~W} / \mathrm{V})$ were prepared in ice cold $10 \mathrm{mM}$ tris buffer (pH7.4). Quantitative estimation of MDA formation was done by determining the concentration of thiobarbituric acid reactive substances (TBARS) in 10\% liver homogenates by the method of Okhawa $^{16}$. Enzymatic antioxidants, superoxide dismutase $(\mathrm{SOD})^{17}$, catalase $(\mathrm{CAT})^{18,19}$ and non enzymatic antioxidant glutathione peroxidase $(\mathrm{GPx})^{20}$ and glutathione reductase $(\mathrm{GRD})^{21}$ were also assayed in liver homogenates.

Table 1: Effect of Canscora perfoliata whole plant extracts on the protein, albumin, globulin concentration and enzyme activity of serum SGOT, SGPT, and ALP in the normal, liver damaged and drug treated rats

\begin{tabular}{|c|c|c|c|c|c|c|c|}
\hline \multirow[t]{2}{*}{ Groups } & \multicolumn{7}{|c|}{ Parameters } \\
\hline & $\begin{array}{l}\text { Total Protein } \\
\text { (mg/dl) }\end{array}$ & $\begin{array}{l}\text { Albumin } \\
\text { (g/dl) }\end{array}$ & $\begin{array}{l}\text { Globulin } \\
\text { (g/dl) }\end{array}$ & $\begin{array}{c}\text { A/G } \\
\text { Ratio }\end{array}$ & $\begin{array}{c}\text { SGOT } \\
(\mathbf{U} / \mathbf{L})\end{array}$ & $\begin{array}{l}\text { SGPT } \\
(\mathbf{U} / \mathbf{L})\end{array}$ & $\begin{array}{l}\mathbf{A L P} \\
(\mathbf{U} / \mathbf{L})\end{array}$ \\
\hline $\mathrm{I}$ & $8.21 \pm 1.56$ & $4.86 \pm 1.21$ & $3.35 \pm 0.31$ & $1.45: 1$ & $28.56 \pm 1.84$ & $31.86 \pm 1.26$ & $163.51 \pm 6.37$ \\
\hline II & $6.13 \pm 0.94 * *$ & $3.76 \pm 0.83 *$ & $2.37 \pm 0.14 *$ & $1.58: 1$ & $38.14 \pm 1.92 * *$ & $49.63 \pm 1.34^{*}$ & $206.46 \pm 8.26^{*}$ \\
\hline III & $6.29 \pm 0.86^{*}$ & $3.89 \pm 0.72$ & $2.40 \pm 0.23$ & $1.62: 1$ & $34.33 \pm 1.46$ & $46.83 \pm 1.27$ & $193.63 \pm 7.14$ \\
\hline IV & $7.96 \pm 1.02$ & $4.06 \pm 0.77$ & $3.90 \pm 0.16$ & 1.04:1 & $29.15 \pm 1.08$ & $32.98 \pm 1.14$ & $178.27 \pm 4.39$ \\
\hline $\mathrm{V}$ & $7.98 \pm 0.93 a$ & $4.86 \pm 0.74$ & $3.12 \pm 0.12$ & $1.55: 1$ & $22.33 \pm 1.61 \mathrm{a}$ & $29.94 \pm 1.19 \mathrm{a}$ & $159.21 \pm 2.83 \mathrm{a}$ \\
\hline
\end{tabular}
treated

Table 2: Effect of Canscora perfoliata whole plant extracts on the serum total, conjugated and unconjugated bilirubin levels in the normal control, liver injured and drug treated rats

\begin{tabular}{|c|c|c|c|}
\hline \multirow{2}{*}{ Groups } & \multicolumn{3}{|c|}{ Parameters } \\
\cline { 2 - 4 } & $\begin{array}{c}\text { Total Bilirubin } \\
(\boldsymbol{\mu m o l} / \mathbf{L})\end{array}$ & $\begin{array}{c}\text { Conjugated } \\
(\boldsymbol{\mu m o l} / \mathbf{L})\end{array}$ & $\begin{array}{c}\text { Unconjugated } \\
(\boldsymbol{\mu m o l} / \mathbf{L})\end{array}$ \\
\hline I & $0.63 \pm 0.11$ & $0.21 \pm 0.03$ & $0.42 \pm 0.01$ \\
\hline II & $2.98 \pm 0.26^{* *}$ & $1.02 \pm 0.11^{*}$ & $1.96 \pm 0.69^{* *}$ \\
\hline III & $2.27 \pm 0.13^{*}$ & $0.98 \pm 0.02^{*}$ & $1.29 \pm 0.37^{*}$ \\
\hline IV & $1.13 \pm 0.27$ & $0.42 \pm 0.05$ & $0.61 \pm 0.04$ \\
\hline V & $0.98 \pm 0.16 \mathrm{a}$ & $0.24 \pm 0.01 \mathrm{a}$ & $0.74 \pm 0.17 \mathrm{a}$ \\
\hline
\end{tabular}

Each Value is $\mathrm{SEM} \pm 5$ individual observations $* p<0.05 ; * * p<0.01$ Compared normal control vs liver injured rats a: $p<0.05$ Compared liver injured rats vs drug

Table 3: Effect of Canscora perfoliata whole plant extracts on liver LPO, GPx, GRD, SOD and CAT in the normal control, liver injured and drug treated rats

\begin{tabular}{|c|c|c|c|c|c|}
\hline \multirow{2}{*}{ Groups } & \multicolumn{4}{|c|}{ Parameters } \\
\cline { 2 - 6 } & $\begin{array}{c}\text { LPO } \\
\text { (n mole of MDA/mg protien) }\end{array}$ & $\begin{array}{c}\text { GPX } \\
\text { (u/mg Protein) }\end{array}$ & $\begin{array}{c}\text { GRD } \\
(\mathbf{u} / \mathbf{m g})\end{array}$ & $\begin{array}{c}\text { SOD } \\
(\mathbf{u} / \mathbf{m g})\end{array}$ & $\begin{array}{c}\text { CAT } \\
(\mathbf{u} / \mathbf{m g})\end{array}$ \\
\hline I & $0.69 \pm 0.04$ & $11.23 \pm 0.83$ & $9.29 \pm 1.01$ & $8.98 \pm 0.14$ & $10.45 \pm 0.21$ \\
\hline II & $3.84 \pm 0.86^{* *}$ & $3.94 \pm 0.31^{* *}$ & $2.08 \pm 0.34^{* * *}$ & $3.26 \pm 0.16^{* *}$ & $3.93 \pm 0.19^{* *}$ \\
\hline III & $2.43 \pm 0.73^{* *}$ & $5.84 \pm 0.24^{* *}$ & $4.63 \pm 0.21^{*}$ & $4.11 \pm 0.16^{*}$ & $6.11 \pm 0.29^{*}$ \\
\hline IV & $1.26 \pm 0.34^{*}$ & $6.93 \pm 0.14 *$ & $4.96 \pm 0.14^{*}$ & $5.19 \pm 0.12$ & $8.56 \pm 0.36$ \\
\hline V & $0.81 \pm 0.24 \mathrm{aa}$ & $9.94 \pm 0.27 \mathrm{aa}$ & $8.23 \pm 0.11 \mathrm{a}$ & $7.4 \pm 0.16 \mathrm{a}$ & $9.98 \pm 0.14 \mathrm{a}$ \\
\hline
\end{tabular}

Compared liver injured rats vs drug treated. 


\section{Statistical Analysis}

The data were expressed as the mean \pm S.E.M. The difference among the means has been analyzed by oneway ANOVA. $p<0.05 ; \quad p<0.01$ and $p<0.001$ were considered as statistical significance using SPSS Software.

\section{RESULTS}

The ethanol extract of whole plant of Canscora perfoliata subjected for phytochemical study showed the presence of alkaloids, coumarin, glycosides, flavonoids, saponins, steroids, phenols, tannins and xanthoproteins. The ethanol extract did not show any sign and symptoms of toxicity and mortality upto $2000 \mathrm{mg} / \mathrm{kg}$ dose. The effect of ethanol extract of Canscora perfoliata on serum total protein, albumin, globulin, $\mathrm{A} / \mathrm{G}$ ratio, serum transaminases, alkaline phosphatases in $\mathrm{CCl}_{4}$ intoxicated rats are summarized in Table 1.

There was a significant $(p<0.01)$ increase in serum GOT, GPT and ALP levels in $\mathrm{CCl}_{4}$ intoxicated group (Group II) compared to the normal control group (Group I). The total protein and albumin levels were significantly $(p<0.01)$ decreased to $6.29 \mathrm{~g} / \mathrm{dl}$ and $3.76 \mathrm{~g} / \mathrm{dl}$ in $\mathrm{CCl}_{4}$ intoxicated rats from the levels of $8.21 \mathrm{~g} / \mathrm{dl}$ and $4.86 \mathrm{~g} / \mathrm{dl}$ respectively in normal group. Ethanol extract of Canscora perfoliata at the dose of 150 and $300 \mathrm{mg} / \mathrm{Kg}$ orally significantly decreased the elevated serum marker enzymes and reversed the altered total protein and albumin to almost normal level.

The effect of ethanol extract of Canscora perfoliata on total, conjugated and unconjugated bilirubin is shown in Table 2. A significant elevation of total, conjugated and unconjugated bilirubin in the serum of $\mathrm{CCl}_{4}$ intoxicated group (Group II) were observed when compared to normal control (Group I). The ethanol extract of Canscora perfoliata at the dose 150 and $300 \mathrm{mg} / \mathrm{Kg}$ reduced the levels of total, conjugated and unconjugated bilirubin (Group III and Group IV). The decreases in the concentration of total bilirubin, conjugated bilirubin and unconjugated bilirubin were found to be greater in standard silymarin (Group V) followed by Group IV and Group III (Table 2).

The effects of ethanol extract of Canscora perfoliata on lipid peroxidation (LPO), Glutathione peroxidase (GPx), Superoxide dismutase (SOD) and Catalase (CAT) activity is shown in Table 3. Lipid peroxidation level was significantly $(p<0.01)$ increased and glutathione peroxidase, glutathione reductase, superoxide dismutase and catalase activity were significantly $(p<0.01)$ decreased in $\mathrm{CCl}_{4}$ intoxicated rats when compared with those of the animals in normal control group. Rats treated with ethanol extract of Canscora perfoliata at the doses of 150 and $300 \mathrm{mg} / \mathrm{kg}$ significantly decreased the elevated lipid peroxidation levels and restored the altered glutathione peroxidase, glutathione reductase, superoxide dismutase and catalase levels towards the normal levels in a dose dependent manner. The results are well comparable with silymarin (standard drug) treated group.

\section{DISCUSSION}

Liver is largest organ and it is target for toxicity because of its role in clearing and metabolizing chemicals through the process called detoxification ${ }^{22}$. Drug induced liver disorders occurred frequently can be life threatening and mimic all forms of liver diseases ${ }^{23} . \mathrm{CCl}_{4}$ is one of the most commonly used hepatotoxin. $\mathrm{CCl}_{4}$ produces an experimental damage that histological resembles viral hepatitis. Toxicity begins with the change in endoplasmic reticulum, which results in the loss of metabolic enzymes located in the intracellular structures ${ }^{24}$. The toxic metabolic, $\mathrm{CCl}_{3}$ radical, is produced and further reacts with oxygen to give trichloromethyl peroxy radical. Cytochrome $\mathrm{P}_{450}$ is the enzyme responsible for this conversion. Both the radicals can bind covalently to the macromolecules and induce peroxidative degradation of the membrane lipid of endoplasmic reticulum rich in polyunsaturated fatty acids ${ }^{24}$. This leads to the formation of lipid peroxidases followed by pathological changes such as depression of protein synthesis, elevation levels of serum marker enzymes such as SGOT, SGPT and ALP, depletion of GPx, GRD, SOD and CAT and increase in lipid peroxidation.

In the present study, it was observed that; the rats treated with $\mathrm{CCl}_{4}$ resulted in significant hepatic damage as shown by the elevated levels of serum markers. These changes in the marker levels will reflect in hepatic structural integrity. The rise in the SGOT is usually accompanied by an elevation in the level of SGPT, which play a vital role in the conversion of aminoacids to keto acids ${ }^{25}$. Ethanol extract of Canscora perfoliata at the doses of $150 \mathrm{mg} / \mathrm{kg}$ and $300 \mathrm{mg} / \mathrm{kg}$ significantly attenuated the elevated levels of the serum markers. The normalization of serum markers by ethanol extract of Canscora perfoliata suggests that they are able to condition the hepatocytes so as to protect the membrane integrity against $\mathrm{CCl}_{4}$ induced leakage of marker enzymes into the circulation. The above changes can be considered as an expression of the functional improvements of hepatocytes.

Alkaline phosphate concentration is related to the functioning of hepatocytes, high level of alkaline phosphatase in the blood serum is related to the increased synthesis of its by cells lining bile canaliculi usually in response to cholestasis and increased biliary pressure ${ }^{26}$. Increased level was obtained after $\mathrm{CCl}_{4}$ administration and it was brought to near normal level by Canscora perfoliata treatment.

Protein metabolism is a major project of liver and a healthy functioning liver is required for the synthesis of the serum proteins. Hypoproteinemia is a feature of liver damage due to significant fall in protein synthesis. Albumin is decreased in chronic liver disease. Hypoproteinemic was observed after $\mathrm{CCl}_{4}$ ingestion but the trend turns towards normal after Canscora perfoliata treatment.

Bilirubin is a yellow pigment produced when heme is catabolised. Hepatocytes render bilirubin water soluble and therefore easily excretable by conjugating it with glucuronic acid prior to secreting it into bile by active transport. Hyperbilirubinemia may result from the production of more bilirubin than the liver can process, damage to the liver impairing its ability to excrete normal amount of bilirubin or obstruction of excretory ducts of the liver ${ }^{27}$. Serum bilirubin is considered as one of the true test of liver functions since it reflects the ability of 
the liver to take up and process bilirubin into bile. Elevated levels may indicate several illness. High levels of total bilirubin in $\mathrm{CCl}_{4}$ treated rats may be due to $\mathrm{CCl}_{4}$ toxicity. This may have resulted in hyperbilirubinemia. The significant reduction in the level of total bilirubin in the serum of Canscora perfoliata whole plant extract treated rats suggested the hepatoprotective potential of whole plant extract against $\mathrm{CCl}_{4}$ intoxication.

Lipid peroxidation has been postulated to the destructive process of liver injury due to $\mathrm{CCl}_{4}$ administration. In the present study, the elevations in the levels of end products of lipid peroxidation in the liver of rat treated with $\mathrm{CCl}_{4}$ were observed. The increase in malondialdehyde (MDA) levels in liver suggests enhanced lipid peroxidation leading to tissue damage and failure of antioxidant defense mechanisms to prevent formation of excessive free radicals. Treatment with ethanol extract of Canscora perfoliata significantly reversed these changes. Hence, it may be possible that the mechanism of hepatoprotection by ethanol extract of Canscora perfoliata is due to its antioxidant effect.

In the present investigations, $\mathrm{CCl}_{4}$ intoxicated rats decreased the content of GPx and GRD in liver, whereas, treatment with ethanol extract of Canscora perfoliata (150 and $300 \mathrm{mg} / \mathrm{kg}$ ) able to reverse such effects. Superoxide dismutase (SOD), a metallo protein is the most sensitive enzyme index in liver injury and one of the most important enzyme in the enzymatic antioxidant defense system. It scavengers the superoxide anion to form hydrogen peroxide and oxygen, hence diminishing the toxic effect caused by this radical ${ }^{28}$. In the present study, it was observed that the ethanol extract of Canscora perfoliata whole plant significantly increased the SOD activity in $\mathrm{CCl}_{4}$ intoxicated rats there by diminished $\mathrm{CCl}_{4}$ induced oxidative damage.

Catalase (CAT) is an enzymatic antioxidant widely distributed in all tissues and the highest activity is found in red cells and liver. Catalase is a heme protein, localized in the peroxisomes or the microperoxisomes. This enzyme catalyses the decomposition of $\mathrm{H}_{2} \mathrm{O}_{2}$ to water and oxygen and thus protecting the cell from oxidative damage by $\mathrm{H}_{2} \mathrm{O}_{2}$ and $\mathrm{OH}$. Therefore, the reduction in the activity of catalase may result in a number of deleterious effects due to accumulation of hydrogen peroxide ${ }^{29}$. In the present study, treatment with ethanol extract of Canscora perfoliata whole plant increased the level of catalase significantly in dose dependent manner and protected the liver from $\mathrm{CCl}_{4}$ intoxication.

In conclusion, the results of this study demonstrate that the ethanol extract of Canscora perfoliata whole plant have a potent hepatoprotective action against $\mathrm{CCl}_{4}$ induced hepatic damage in rats. It's mode in affording the hepatoprotective activity against $\mathrm{CCl}_{4}$ induced liver damage may be due to cell membrane stabilization, hepatic cells regeneration and enhancement of antioxidant enzymes such as catalase, superoxide dismutase and glutathione peroxidase production. The hepatoprotective and antioxidiant potential of whole plant extract could have been brought about by various phytochemical principles i.e. flavonoids, alkaloids, phenolics and tannins present in Canscora perfoliata whole plant. So results of this study demonstrated that the Canscora perfoliata has significantly protection on $\mathrm{CCl}_{4}$ induced hepatotoxicity.

\section{ACKNOWLEDGEMENT}

Thanks to Dr. Sampathraj, Honorary Advisor, Samsun Clinical Research Laboratory, Tirupur for their assistance in animal studies.

\section{REFERENCES}

1. Ahsan R, Monirul Islam KM, Musaddik A, Hague E. Hepatoprotective activity of methanol extract of some medicinal plants against carbon tetrachloride induced hepatotoxicity in albino rats. Glob J Pharmacol 2009; 3: 116-122.

2. Nazemma TH, Brindha V. Antihepatotoxic and antioxidant defense potential of Mimosa pudica. Int J Drug Discov 2009; 1: 1-14.

3. Manokaran S, Jaswanth A, Sengottuvelu S, Nandhakumar J, Duraisamy R, Karthikeyan, D. et al., Hepatoprotective activity of Aerva lanata Linn against paracetamol induced hepatotoxicity in rats. Research J Pharm and Tech 2008; 1: 398-400.

4. Rachehh MA, Yadav PN, Cokani RH, Jain SM. Antiinflammatory activity of Benincasa hispid fruit. Int J Phar Biosci 2011; 2: 98106.

5. Muthukumarasamy S, Mohan VR, Kumaresan S, Chelladurai V. Herbal remedies of Palliyar tribe of Grizzled Giant Squirrel Wildlife Sanctuary, Srivilliputhur, Western Ghats, Tamil Nadu for poisonous bites. J Econ Taxon Bot 2003; 27: 761-764.

6. Das KK, Das SN, Das Gupta S. The influence of ascorbic acid against nickel-induced hepatic lipid peroxidation in rats. J Basic Clin. Physiol. Pharmacol 2001; 12: 187-195. http://dx.doi.org/10.1515/JBCPP.2001.12.3.187 PMid:11762690

7. Premila Abraham P, Wilfred G, Ramakrishna B. Decreased activity of hepatic alkaline protease in rats with carbon tetrachlorideinduced liver cirrhosis. Indian J Exp Biol 1999; 37: 1234-1244.

8. Brinda P, Sasikala P, Purushothaman KK: Pharmacognostic studies on Merugan kizhangu. Bulletin in Medical Ethnobotanical Research 1981; 3:84-96.

9. Anonymous: Phytochemical investigation of certain medicinal plants used in Ayurveda. Central Council for Research in Ayurveda and Siddha, New Delhi. 1990.

10. Lala PK: Lab manuals of Pharmacognosy CSI Publishers and Distributers, Kolkata. 1993.

11. OECD, (Organisation for Economic co-operation and Development). OECD guidelines for the testing of chemicals/Section 4: Health Effects Test No. 423; Acute oral Toxicity- Acute Toxic Class method. OECD. Paris. 2002.

12. Lowry $\mathrm{OH}$, Rosenbrough NJ, Farr AL, Randall RJ. Protein measurement with the Folin's phenol reagent. Journal of Biological Chemistry 1951; 193: 265-275. PMid:14907713

13. Reitman S, Frankel SA. Colorimetric method for the determination of serum glutamic oxaloacetic and glutamic pyruvic transaminases. American Journal of Clinical Pathology 1957; 28: 56-63. PMid: 13458125

14. King EJ, Armstrong AR. Determination of serum and bile phosphatase activity. Cannadian Medical Association Journal 1934; 31: 56-63.

15. Balistrei WR, Shaw LM. Liver function In: Fundamental of Clinical Chemistry, (Ed) Tietz N.W. 3rd edition. W.B. Saunders Company, Philadelphia, 1987. p. 729-761.

16. Okhawa H, Ohishi N, Yagi K. Assay of lipid peroxidases in animal tissues by thiobarbituric acid reaction. Analytical Biochemistry 1979; 95: 351-358. http://dx.doi.org/10.1016/0003-2697(79)907383

17. Mishra HP, Fridowich I. The role of superoxide dismutase anion in antioxidation of epinephrine and sample assay in superoxide dismutase. Journal of Biological Chemistry 1972; 241: 3170.

18. Aebi H. Catalase, in Methods of enzymatic analysis. Bergmayer H.U. (Ed) chemie, $2^{\text {nd }}$ edn. Weinheim: F.R.G; 1974. 673-684.

19. Colowick SP, Kaplan NO, Packer L. Methods in Enzymology. Academic press, London; 1984. p.121-125.

20. Pagila DE, Valentine WN. Studies on the quantitative and qualitative characterization of erythrocyte glutathione peroxidase. Journal of Laboratory and Clinical medicine 1967; 70: 158-169.

21. Goldberg DM, Spooner RJ. Glutathione Reductase, In: Methods in Enzymatic Analysis, VCH Weinhem, Germany 1983; 258-265. PMid:6312299 
22. Larrey D. Drug induced liver diseases. J Hepatol 2003; 32: 77-88. http://dx.doi.org/10.1016/S0168-8278(00)80417-1

23. Watkins PB, Seeff LB, Drug-induced liver injury: summary of a single topic clinical research committee. Hepatology 2006; 43:618631. http://dx.doi.org/10.1002/hep.21095 PMid:16496329

24. Recknagel RO. A new direction in the study of carbon tetrachloride hepatotoxicity. Life Sci 1983 ; 33: 401-408. http://dx.doi.org/ 10.1016/0024-3205(83)90787-7

25. Suky TMB, Parthipan B, Kingston C, Mohan, VR, Tresina Soris, P. Hepatoprotecive and antioxidant effect of Balanites aegyptiaca (L.) Del against $\mathrm{CCl}_{4}$ induced hepatotoxicity in rats. Int $\mathrm{J}$ Pharmaceu Sci Res 2011; 2: 887-892.

26. Graw A, Cowan RA, O'Reilly DSJ, Stevant MJ, Stephard J. Clinical biochemistry- an illustrated color text. Is ted. New York: Churchill Livingstone; 1999. p 51-53.
27. Olaleye M, Afolabi C, Adebayo A, Ogunboye A, Akindahunsi A Antioxidant activity and hepatoprotective property of leaf extracts of Boerhaavia diffusa Linn against acetaminophen-induced liver damage in rats. Food Chem Toxicol 2010; 48: 2200-2205 http://dx.doi.org/10.1016/i.fct.2010.05.047 PMid:20553784

28. Curtis SJ, Moritz M, Snodgrass PJ. Serum enzymes derived from liver cell fractions and the response to carbon tetrachloride intoxication in rats. Gastroenterology 1972; 62:84-92. PMid:5059436

29. Chance B, Green Stein DS, Roughton RJW. The mechanism of catalase action 1-steady state analysis. Arch Biochem Biophys.1952; 37: 301- 339. http://dx.doi.org/10.1016/00039861(52)90194-X

\section{Cite this article as:}

Thangakrishnakumari S, Nishanthini A, Muthukumarasamy S, Mohan V.R. Hepatoprotective and antioxidant activity of Canscora perfoliata Lam (Gentianaceae) against $\mathrm{CCl}_{4}$ induced hepatotoxicity in rats. Int. J.

Res. Ayur. Pharm. 2012; 3(6):822-826 